\title{
The combined use of platinum nanoparticles and hydrogen molecules induces caspase-dependent apoptosis
}

\author{
Takeki Hamasaki ${ }^{1}$, Tomoya Kinjyo ${ }^{2}$, Hidekazu Nakanishi ${ }^{2}$, Kiichiro Teruya ${ }^{1,2}$, Sigeru Kabayama ${ }^{3}$, \\ Sanetaka Shirahata ${ }^{1,2^{*}}$
}

From 23rd European Society for Animal Cell Technology (ESACT) Meeting: Better Cells for Better Health Lille, France. 23-26 June 2013

We previously reported electrochemically reduced water (ERW), produced near the cathode by electrolysis, exhibits reductive activity. We also revealed that ERW contains Pt nanoparticles (Pt nps) derived from Pt-coated titanium electrodes in addition to high concentration of dissolved molecular hydrogen $\left(\mathrm{H}_{2}\right)$ by in vitro assay, and Pt nps exhibit powerful ROS scavenger activity and catalysis activity converting $\mathrm{H}_{2}$ to active hydrogen. Our study investigates apoptosis inducibility of $\mathrm{H}_{2}$ and synthesized Pt nps on human promyelocytic leukaemia HL60 cells. Human promyelocytic leukaemia cells (HL60) were cultured in RPMI 1640 medium supplemented with $10 \%$ FBS, $2.0 \mathrm{mM}$ l-glutamine, $100 \mathrm{U} / \mathrm{ml}$ penicillin and $100 \mathrm{U} / \mathrm{ml}$ streptomycin. Cultures were incubated in an atmosphere of $75 \%(\mathrm{v} / \mathrm{v}) \mathrm{H}_{2} / 20 \%(\mathrm{v} / \mathrm{v})$ $\mathrm{O}_{2} / 5 \%(\mathrm{v} / \mathrm{v}) \mathrm{CO}_{2}, 75 \%(\mathrm{v} / \mathrm{v}) \mathrm{He} / 20 \%(\mathrm{v} / \mathrm{v}) \mathrm{O}_{2} / 5 \%(\mathrm{v} / \mathrm{v}) \mathrm{CO}_{2}$ atmosphere or $75 \%(\mathrm{v} / \mathrm{v}) \mathrm{N} 2 / 20 \%(\mathrm{v} / \mathrm{v}) \mathrm{O}_{2} / 5 \%(\mathrm{v} / \mathrm{v}) \mathrm{CO}_{2}$ atmosphere for 12-48 hr after incubated with Pt nps for $2 \mathrm{~h}$. Untreated cultures were included as controls. Cytotoxicity was determined by cell-counter. Apoptosis pathway of HL60 cells was investigated by Sub G-1 assay.

Growth suppression was not observed when cells were treated with Pt nps or $\mathrm{H}_{2}$ only. Analysis of cell cycle and activity of caspase- 3 suggested that combination use of both Pt nps and $\mathrm{H}_{2}$ induced apoptosis in HL60 cells. Our caspase activity experimentation suggests that apoptosis was caused via caspase- 8 activation. These results suggested that atomic hydrogen from $\mathrm{H}_{2}$ induces caspase- 8 dependent apoptosis. The cytotoxicity was not detected in Pt nps or $\mathrm{H}_{2}$ separately treated cells.

\footnotetext{
* Correspondence: sanetaka@grt.kyushu-u.ac.jp

'Department of Bioscience and Bioengineering, Faculty of Agriculture,

Kyushu University, 6-10-1 Hakozaki, Higashi-ku, Fukuoka 812-8581, Japan
}

Full list of author information is available at the end of the article
Apoptosis was determined only when cells were treated with both Pt nps and $\mathrm{H}_{2}$, suggesaspase- 8 dependent apoptosis was caused by atomic hydrogen produced from $\mathrm{H}_{2}$ by catalyst activity of Pt nps.

\section{Authors' details}

'Department of Bioscience and Bioengineering, Faculty of Agriculture, Kyushu University, 6-10-1 Hakozaki, Higashi-ku, Fukuoka 812-8581, Japan. ${ }^{2}$ Graduate School of Systems Life Sciences, Kyushu University, 6-10-1 Hakozaki, Higashi-ku, Fukuoka 812-8581, Japan. ${ }^{3}$ Nihon Trim Co. LTD., 34-8-1 Ooyodonaka, Kita-ku, Osaka 531-0076, Japan.

Published: 4 December 2013

\section{doi:10.1186/1753-6561-7-S6-P109}

Cite this article as: Hamasaki et al.: The combined use of platinum nanoparticles and hydrogen molecules induces caspase-dependent apoptosis. BMC Proceedings 2013 7(Suppl 6):P109.

Submit your next manuscript to BioMed Central and take full advantage of:

- Convenient online submission

- Thorough peer review

- No space constraints or color figure charges

- Immediate publication on acceptance

- Inclusion in PubMed, CAS, Scopus and Google Scholar

- Research which is freely available for redistribution

Submit your manuscript at www.biomedcentral.com/submit
() Biomed Central 